\title{
Community Driven Beach Management Practices: Case Study Velas, Kelshi, Anjarla Villages of India
}

\author{
Deepti Sharma ${ }^{1,}$, Nisha Pandey ${ }^{2}$ \\ ${ }^{1}$ Terra Nero Environmental Solutions Pvt. Ltd, Mumbai, India \\ ${ }^{2}$ Vivekanand Education Society Institute of Management, Mumbai, India
}

Email address:

s.deepti.s@gmail.com (D. Sharma)

${ }^{*}$ Corresponding author

\section{To cite this article:}

Deepti Sharma, Nisha Pandey. Community Driven Beach Management Practices: Case Study Velas, Kelshi, Anjarla Villages of India. International Journal of Sustainability Management and Information Technologies. Vol. 6, No. 1, 2020, pp. 1-12. doi: 10.11648/j.ijsmit.20200601.11

Received: May 1, 2019; Accepted: June 17, 2019; Published: January 7, 2020

\begin{abstract}
The beaches of Konkan are scenic and attractive from the tourism point of view. At the same time, they are rich in intertidal and marine biodiversity. The same natural resource used by various stakeholders has historically led to conflicts and managerial issues. An important dimension worth noting is that natural resources have their rate of renewability that may not match the price at which they are being harvested. Therefore, in the best interest of all, it is desirable that natural resource depletion is minimised and best management practices are strictly followed. The first step is to identify all possible stakeholders in the management of the concerned natural resource. Secondly, they will have to be made aware of the situation and thirdly, by involving all of them, equitable distribution of funds based firmly on the foundation of sustainable use and resource replenishment is achieved. On this background, this study provides a state of the situation of the beach of three study villages - Velas, Kelshi and Anjarla in Konkan region. In the initial part of this report, an overview of management challenges and policy provisions for beaches is provided. This is followed by a section on the setting of the study villages and study methodology. In the following sections, existing practices related to the beach in the study villages are explained. In the concluding section a brief of beach management in all study villages and follow up action is provided.
\end{abstract}

Keywords: Beach Management, Policy Issues, Natural Resources, Marine Biodiversity

\section{Introduction}

\subsection{Coastal Ecosystem: Management Challenges}

Our coasts and beaches are precious natural resources being used by a multitude of stakeholders. A large portion of international trade is mediated via the sea-route, making ports along the coast of prime commercial importance. The fishing community relies on the intertidal zone and offshore areas for sustenance. The tourism industry flourishes along the beaches, offering direct contact with the sea as the key attraction. At the same time, the sea, believed to have an enormous remediation capacity, receives treated, partially treated or even untreated sewage and industrial effluent, apart from solid waste, from seaside settlements. The Hindu religious tradition of idol immersion in water has ensured that at least twice a year (Ganapati festival and Durga Puja), thousands of small to large Plaster-of-Paris or clay idols find their way into the waters along with flowers and coconuts in the offering. Coastlines are matters of national security as well. Among these, the most silent stakeholder is the intertidal/coastal biodiversity.

Coastal biodiversity includes some of the most important, most sensitive, most vulnerable and most threatened ecosystems such as mangroves, coral reefs, estuarine areas, and intertidal zone. Besides, the coast is the interface between sea and land, health, biodiversity, ecosystemproductivity and pollution-free status of the open seas is also connected with proper coastal management.

\subsection{Study Area Details}

Velas is located in Mandangad taluka of Ratnagiri district in coastal Maharashtra. It is situated at the northern boundary of the region, near the mouth of Savitri River (17'57'27.7’ N 
and $73^{\circ} 01^{\prime} 55.0^{\prime \prime}$ E). Since 2006 , it has been a prominent tourist site due to the Turtle festival it hosts each year. There is an estuary in the north and a rocky patch in the south, which is bordered by natural vegetation and a freshwater stream. Casuarina plantations and Ipomea Biloba surround most of the beach. The beach is about $2 \mathrm{~km}$ in length.

Kelshi is situated to the south of Velas in Dapoli taluka of Ratnagiri district $\left(17^{\circ} 55^{\prime} 11.4^{\prime \prime} \mathrm{N}\right.$ and $\left.73^{\circ} 03^{\prime} 16.5^{\prime \prime} \mathrm{E}\right)$. The coastline of Kelshi stretches for approximately $5 \mathrm{~km}$ and has both sandy and rocky shores. The beach is entirely abutted by casuarina plantations. There is an inlet on the north and a large rocky patch on the south, where Indian screw pine
(Pandanus sp.) and Ipomoea biloba are predominant.

Anjarla is located in the south of Kelshi in Dapoli taluka of Ratnagiri district $\left(17^{\circ} 50^{\prime} 47.6^{\prime \prime} \mathrm{N}\right.$ and $\left.073^{\circ} 05^{\prime} 20.5^{\prime \prime} \mathrm{E}\right)$. There is estuary on the south and a rocky patch on the north. The beach is flanked by Coconut and Betelnut plantations, Mango groves, Casuarina plantation and wild pieces of Indian screw pine and Anjarla has a broad dissipative beach, which narrows intermittently towards the south.

Figure 1 below is a Google image depicting the geographical location of the study villages. Demographic details are given in Table 1.

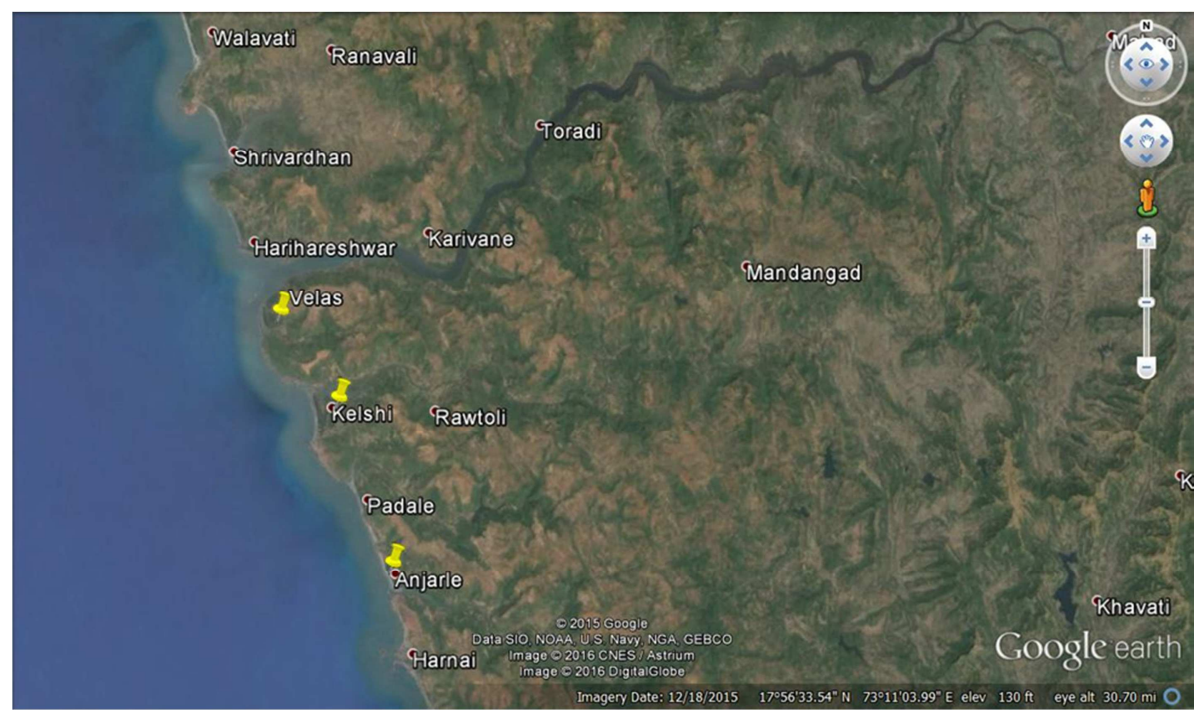

Figure 1. Geographical Location of Study Villages.

Table 1. Population of the Study Villages as per Census 2011.

\begin{tabular}{llll}
\hline Particular & Velas & Kelshi & Anjarla \\
\hline Total & 506 & 3145 & 1394 \\
Male & 306 & 1472 & 672 \\
Female & 276 & 1673 & 722 \\
Literacy (\%) & 77 & 81 & 83 \\
\hline
\end{tabular}

\section{Literature Review}

\subsection{Olive Ridley Turtle Nesting}

The Olive Ridley turtle (Lepidochelys olivacea) is a medium-sized marine turtle, found in the Pacific and Indian oceans. It is categorised as 'vulnerable' (VU) by the IUCN. Olive Ridley sea turtle is a Schedule - I animal as per the Indian Wildlife (Protection) Act, 1972. It is protected under the Convention on the Conservation of Migratory Species of
Wild Animals and the Convention on International Trade in Endangered Species of Wild Fauna and Flora. India is a party to both of them.

These turtles show an unusual mass nesting behaviour termed arribada, a term which means 'arrival by the sea' in the Spanish language. The Odisha beach is particularly wellknown for mass nesting phenomenon of Olive Ridley.

Turtle nesting grounds are sensitive to coastal ecosystems. In India, they are protected as CRZ - I as per the Coastal Regulation Zone Notification (2011). Nesting beaches are usually relatively flat, mid-beach zone, and free of debris $[1,2]$.

From the conservation point of view, it is essential to protect beaches known for turtle nesting from littering and hectic beach activity because the turtle females remember the beach where they had emerged as hatchlings. They return to the same beach for laying their eggs [3].

Table 2. Olive Ridley Turtle Details.

\begin{tabular}{ll}
\hline Weight & Adult: 100 pounds $(45 \mathrm{Kg})$; Hatching: $<1$ ounce $(28 \mathrm{~g})$ \\
Length & Adult: $22-31$ inches $(55-80 \mathrm{~cm})$; Hatching: 1.5 inches $(4 \mathrm{~cm})$ \\
Appearance & Olive/Grayish-green with heart-shaped top shell \\
Lifespan & Unknown, but they reach sexual maturity at about 15 years \\
Diet: & Algae, Lobster, Crabs, Tunicates, Mollusks, Shrimp and Fish \\
Behaviour & Vast numbers of olive ridley turtles come ashore and nest in what is known as an "arribade"; females near every year, once or twice in a \\
\hline
\end{tabular}

Source: http://www.nmfs.noaa.gov/pr/species/turtles/oliveridley.htm. 


\subsection{Policy and Legislation}

\section{Wildlife (Protection) Act, 1972}

The Wildlife (Protection) Act, 1972 brought into sharp focus the importance of conservation of India's wildlife. The highlights of the Act are:

The Wildlife Protection Act, 1972, provides for protection to listed species of flora and fauna and establishes a network of ecologically-important Protected Areas. The Act consists of 60 sections and six schedules- divided into eight Chapters. The Wildlife Protection Act, 1972 empowers the Central and State governments to declare any area as a wildlife sanctuary, national park or closed area. There is a blanket ban on carrying out any industrial activity inside these Protected Areas. It provides for authorities to administer and implement the Act; regulate the poaching of wild animals, protect specified plants, Sanctuaries, National Parks and closed areas, restrict trade or commerce in wild animals or animal articles, and miscellaneous matters. The Act prohibits poaching of animals except with permission of authorised officer when an animal has become dangerous to human life or property or as disabled or diseased as to be beyond recovery.

Olive Ridley sea turtle is listed in Schedule - I of the Act, under which its poaching is strictly prohibited.

Coastal Regulation Zone Notification, 2011

India's coastal and marine environments are under increasing pressure from urban development, tourism, recreational activities and resource exploitation. Several official reports were prepared on the subject, with the result that in the year 1981, the Government of India notified that owing to their aesthetic and environmental value, beaches had to be kept clear of all activities up to $500 \mathrm{~m}$ from the highest water line. To control, minimise and to protect sensitive coastal stretches from unplanned human interference, in 1991, The Government of India, framed rules for the regulation of various Coastal Zone activities and notified them under the Environment Protection Act, (1986). This notification is called the Coastal Regulation Zone (CRZ) information (1991). The rules were revised subsequently as per the recommendations of the expert committee headed by Prof. M. S. Swaminathan. The revised regulations were notified in 2011. Thus the existing notification is called CRZ notification (2011).

As per the CRZ notification (2011), the Coastal Zones are demarcated into zones four zones termed zones I to IV. Of this, CRZ I includes ecologically sensitive regions, granting them protection from any activity other than a few government-related ones.

The CRZ I includes "ecologically sensitive areas like mangroves (if area more than 1000 square meters, a buffer area of 50 meters shall be provided), corals, sand dunes, salt marshes, bird \& turtle nesting grounds, horseshoe crab habitats, seagrass beds, mudflats and the area between Low Tide Line and High Tide Line; also - National Parks, Marine Parks, Sanctuaries, reserve forests, wildlife habitats and other
Protected Areas under the provisions of Wild Life (Protection) Act, (1972), the Forest (Conservation) Act, (1980) or Environment (Protection) Act, (1986) ; including Biosphere Reserves \&areas or structures of archaeological importance and heritage sites."

\subsection{Turtle Tourism in Other Parts of the World}

Olive Ridley mass nesting events or 'arribadas' have been documented in Odisha state since 1974 [4]. Gahirmatha Beach near the Bhitarkanika Wildlife Sanctuary is particularly well-known for the turtle arribadas. Local communities reportedly avoid poaching the turtle, instead of providing them protection during the nesting. During a 1995 study by the Wildlife Institute of India (WII), the local community was engaged in the experimental procedures of tagging turtles and data collection.

Martin (2013) reports successful clean-up of the beaches of Jekyll Island, Georgia, USA for one year by local citizens wherein 200 volunteers donated 460 working hours. This was taken up as a citizen science project by the Georgia Sea Turtle Center (GSTC), which is a state-of-the-art facility focused on sea turtle rehabilitation, research, and education. An exercise such as this helps provide participants with the ability to feel part of a larger initiative, in turn, feel like they are making more of an impact. Educating individuals and inspiring them to participate adds to the significance of both removals of marine debris in coastal sea turtle habitat and education to aid in the prevention of further pollution. Once in the marine environment, waste poses a significant threat to marine life that can be prevented through the help of citizen science. Marine debris is any manufactured item that enters the ocean regardless of source, commonly plastics, metal, wood, glass, foam, cloth, or rubber. Citizen science is an effective way to engage volunteers in conservation initiatives and provide education and skill development. [5]

Campbell (1999) reports Olive Ridley turtle-based rural eco-tourism in the Costa Rican village of Ostional. In 1995, only four per cent of Ostional households identified tourism as a source of income; however, this was substantial in comparison to that derived from other economic activities. While most Ostional residents had positive attitudes toward tourism, they had limited awareness of employment or investment opportunities. Lack of knowledge and increased activity by outside investors were listed as significant challenges by the researchers. The researchers opine that in the absence of formalised planning or intervention, the possibilities for the community at Ostional to further benefits from tourism development will be limited. [6]

Objectives of the Research:

1. To identify stakeholders in beach management in the study villages.

2. To interact with the stakeholders in beach management to document their interaction with the beach and utilisation of the beach by each of them.

3. To develop the profile of beach litter in the study villages. 


\section{Methodology}

\subsection{Stakeholder Identification}

Stakeholders in beach management are the individuals or institutions, private or public, having an interest or concern in the beach due to any of these reasons: livelihood, recreation, regulation and commercial use. For developing a beach management protocol, it is necessary that all possible stakeholders are identified. In the protocol, roles and responsibilities of each stakeholder will be mentioned. For this report, the stakeholders in beach management have been determined based on, (i) earlier SNM report on stakeholders in natural resource management in the study villages, (ii) discussions with the field contact persons of SNM and, (ii) field observations of the research team. The identified stakeholders are listed in Table 3 and have been described in the analysis section. The stakeholders were interviewed to document their interaction with the beach and the utilisation of the beach.

Table 3. Stakeholders in Beach Management.

\begin{tabular}{|c|c|c|c|}
\hline \multicolumn{2}{|l|}{ Local } & \multicolumn{2}{|l|}{ Non-local } \\
\hline Individual and Private & Institutional and Public & Personal and Private & Institutional and Public \\
\hline Fishers - small boats & Gram Panchayat & Sand dredger drivers & Forest Department \\
\hline $\begin{array}{l}\text { Casual visitors - villagers doing } \\
\text { small scale on-shore fishing }\end{array}$ & $\begin{array}{l}\text { Joint Forest Management } \\
\text { Committee }\end{array}$ & Ferry boat drivers & $\begin{array}{l}\text { Agriculture and Kharland } \\
\text { development }\end{array}$ \\
\hline Waste collectors and Recyclers & Kasav Mitra Mandal & Tourists & Customs \\
\hline Fishers - trawlers & Hospitals and Dispensaries & Tour operators & Coastguard \\
\hline Homestay operators & Women SHGs & SNM & Ferry operation company \\
\hline & & & Mining Company \\
\hline & & & PWD \\
\hline & & & Fishery Department \\
\hline
\end{tabular}

\subsection{Interaction with the Stakeholders in Beach Management}

A set of standard questions was prepared to interact with each stakeholder in the beach management. This open-ended questionnaire covered aspects like cause or motive of interaction with the beach, frequency and periodicity of communication and general practices concerning littering and waste refusal on the beach. In each study village, 25 households were randomly interviewed to cover the community as stakeholders in beach management. This number of families constituted more than $5 \%$ of the total number of homes in each study village. According to Israel (1992), 5\%-10\% of the population is sufficient to constitute the sample size. Due to time and travel limitations, other stakeholders were purposively interviewed at their location or over the telephone. [7]

\subsection{Profiling of Litter and Waste on the Beach}

To document litter and waste found on the beach, periodic observations and measurements were conducted. For weighing the litter, it was collected from $100 \mathrm{~m}$ section of each beach following Schulz et al. (2015) [8]. Essentially the collection method is as per the guidelines of the Convention for the Protection of the Marine Environment of the NorthEast Atlantic (the 'OSPAR Convention') (Refer Annexure II).

The waste was segregated into individual types. Each type of, for example, glass waste, rubber waste, religious waste, medical waste, fishing nets, oil goop, wood waste was weighed using spring balance. $[9,10]$

To check the quantity of waste that washed over to the three beaches from the sea by high tide, the collection and weighing on each beach was done just before high tide and after high tide. To understand the role of tourists in a solid waste generation on the beaches, these measurements were conducted thrice during pre-tourism peak period and the post-tourism peak period in the same month. For each beach, a total of 4 observations was done (during and before Diwali in November 2015 and during and before New Year's Eve in December 2015).

\section{Analysis and Discussion}

\subsection{Stakeholders in Beach Management}

Fishers - small boats: Small boat operators contribute to floating thermocol pieces which they use for their floats of the fishing nets. Even damaged fishing nets are seen washed ashore.

Fishermen - trawlers: Fishing trawlers are vessels which are designed to operate fishing trawls. Trawling is pulling or dragging trawl through the water behind one or more trawler. These trawlers go for fishing in the oceans for more than two days. These are mechanised vessels.

Ferry boat drivers: Ferry boats non-mechanised vessels which are used for transportation of people and their goods. Currently, this service is being used at Anjarle.

Tourists: Tourist comes to all these three villages for their beaches. And also to enjoy village life. Velas is famous for its Olive ridley sea turtles, the tourism here is dependent or limited to that season only. Very few tourists visit Velas apart from turtle festival.

SNM: Few like-minded people started SNM (Sahyadri Nisarga Mitra) intending to 'Broaden the vision of nature conservation'. It was established on 12th Feb 1992. They are working on the conservation of Olive ridley sea turtles; White backed Vultures, White-bellied sea eagles and other 
extraordinary animals.

Hospitals and dispensaries: Hospitals and dispensaries contribute to medical waste which is if not correctly disposed of it might harm livestock as well as it can also impact human health severely.

Gram Panchayat: Gram Panchayats are local government bodies at the village level. The Gram Panchayat is the foundation of the Panchayat System. A Gram Panchayat can be set up in villages with a population of more than five hundred. There is a common Gram Panchayat for two or more communities if the people of these villages is less than five hundred. It is called Group-Gram Panchayat.

The Panchayat Act specifies the functions, powers and duties of the Gram Panchayats. A Gram Panchayat shall provide for:

1. Sanitation, conservancy and drainage and the prevention of public nuisances;

2. Curative and preventive measures in respect of any epidemic;

3. Supply of drinking water and disinfecting the sources of amount and storage of water;

4. The maintenance, repair, construction and protection of public streets;

5. The removal of encroachments of public roads or public places;

6. The management and care of open tanks;

7. Organising voluntary labour for the upliftment of its area;

8. The control and administration of the Gram Panchayat Fund;

9. The imposition, assessment and collection of the taxes, rates or fees;

10.The maintenance and inspection of Dafadars and Chowkidars;

11. Administration of Nyay Panchayat, etc.

Other Functions Assigned by the State Government:

1. Primary, social, technical, vocational, adult or nonformal education;

2. Rural dispensaries, health centres, maternity and child welfare centres;

3. Management of any public ferry;

4. Irrigation;

5. Improved breeding of cattle;

6. Bringing wasteland under cultivation through land improvement and soil conservation;

7. Promotion of village plantations, social forestry and farm forestry;

8. Women and child development;

9. The advertising and encouragement of cottage, khadi, village and small-scale including food processing industries. [11]

\subsection{Joint Forest Management Committee}

As per the provisions of National Forest Policy (1988), the Government of India, vide letter NO. 6.21/89-PP dated $1^{\text {st }}$ June 1990, outlined and conveyed to State Governments a framework for creating massive people's movement through the involvement of village committees for the protection, regeneration and development of degraded forest lands. This gave impetus to the participation of stakeholders in the management of degraded forests situated in the vicinity of villages. The joint forest management programme in the country is structured on the broad framework provided by the guidelines issued by the Ministry. So far, during the last ten years, 27 State Governments have adopted resolutions for implementing the JFM programme in their respective states. As on 15.8.2001, 14254845.95 ha of forests lands are being managed under JFM programme through 62890 committees.

\subsection{Participation of Women in the JFM Programme}

i. At least $50 \%$ of members of the JFM general body should be women. For the public body meeting, the presence of at least $50 \%$ women members should be a prerequisite for holding the general body meeting.

ii. At least $33 \%$ of the membership in the JFM Executive Committee/ Management Committee should be filled from amongst the women members. The quorum for holding a meeting of such Executive/ Management Committee should be one-third of women executive members or a minimum of one whichever is more. One of the posts of an office bearer, i.e. President/ VicePresident / Secretary should be filled by women members of the Committee. [12]

\section{Homestay operators (Kasav Mitra Mandal)}

Homestay owners are household owners who provide tourists with their food (traditional) as well as look after their homely accommodation. They are the main component in tourism as many tourists are dependent on them and also homestay owners are reliant on tourism.

Waste and rag pickers

Waste and rag pickers are also equally important as without them it is almost impossible to remove waste from villages and take it to proper fate.

Casual visitors - villagers doing small scale on-shore fishing

These are fishermen who do not own the boat and are fishing for crabs onshore (Rocky as well as Sandy and even in mangroves).

Biodiversity committees and Researchers

Biodiversity committees must be informed regarding any research activity in any of these villages. Students or researchers who come to these three villages to work on their research project are also can be considered as stakeholders.

Cattle owners

They send their cattle for grazing in open fields. Cattles in Velas go on the beach for grazing on nearby vegetation and in other two villages animals use the beach as short cut route to their daily grazing land or fields.

Tour Operators

Tour operators such as Mumbai Travellers, Trek Mates India and Treks and Trails India conduct tours from Mumbai and Pune for turtle tourism.

Forest Department

The Government of Maharashtra created the Mangrove 
Cell on January 05, 2012 to protect, conserve and manage the mangroves of the State. The creation of the Mangrove Cell is an essential step in the conservation and management of mangroves in the State. The Cell has also been given the additional responsibility of protection of coastal biodiversity; an area seldom paid the attention it deserves. The Cell is headquartered in Mumbai and headed by a Chief Conservator of Forests.

The Mangrove Cell of the Forest Department has been an active initiator in mangrove conservation, associated livelihoods and other relevant issues. [13, 14]

\section{The Indian Coast Guard}

The Indian Coast Guard protects India's maritime interests and enforces maritime law, with jurisdiction over the territorial waters of India, including its contiguous zone and exclusive economic zone (EEZ). The Indian Coast Guard was formally established on 18 August 1978 by the Coast Guard Act, 1978 of the Parliament of India as an independent
Armed Force of India. It operates under the Ministry of Defence.

The Coast Guard works in close cooperation with the Indian Navy, the Department of Fisheries, the Department of Revenue (Customs) and the Central and State police forces. The Indian Coast Guard is a multi-mission organisation concerned with diverse aspects of sea and coastal issues such as coastal protection, saving the lives of endangered seafarers and fishers, apprehending smuggler and poachers and even taking care of marine biodiversity.

With a 7,517-km long coastline, India is located centrally at the crossroads of trans-Indian Ocean routes. Most cargo ships that sail between East Asia, America, Europe and Africa pass through Indian territorial waters. This has paid enormously to India's growth and played a significant role in making India one of the fastest growing economies in the world. The fact that around $95 \%$ of India's trade by volume and $70 \%$ by value is done through maritime transport. [15]

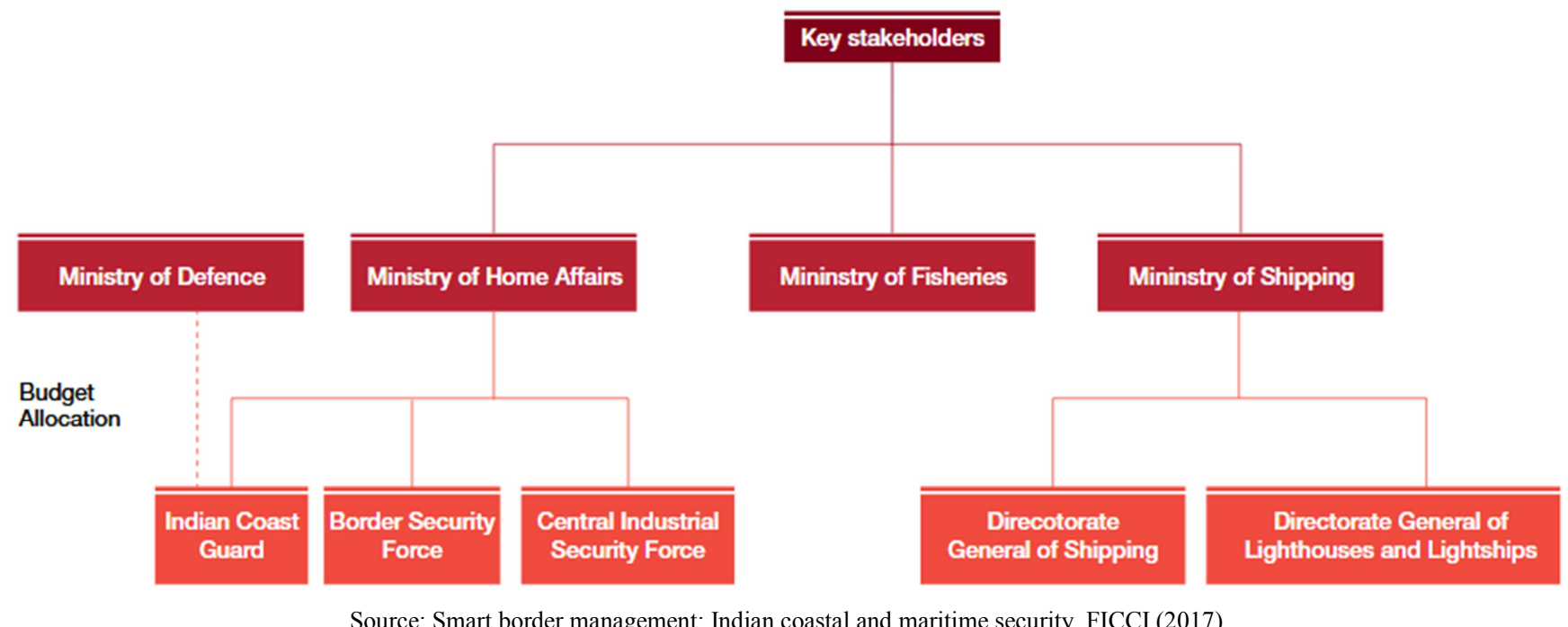

Figure 2. Key Stakeholder in Indian Coast Security [16].

1. Safety and Protection of Artificial Islands and Offshore Terminals

Coast Guard ships and aircraft undertake regular patrols to keep the Offshore Development Areas (ODAs), on both the Eastern and Western seaboard under surveillance.

2. Protection of Fishermen

Coast Guard ships and shore establishments conduct regular Community Interaction Programmes (CIPs) to apprise the fisher-folk about safety measures to be adopted at sea. Information regarding upkeep and maintenance of boats and fishing gear is also imparted. Maritime security related aspects are also disseminated to fisherfolk.

3. Assistance to Fishermen in Distress at Sea

The Maritime Rescue Coordination Centers (MRCCs) colocated with RHQs, coordinate the Search and Rescue (SAR) efforts undertaken by Coast Guard units. Effective liaison is also maintained with the concerned state government departments for expeditious launch of SAR missions and their successful culmination. [17]

Customs Officials
The Central Board of Excise and Custom is the national nodal agency responsible for administering Customs, Central Excise, Service Tax \& Narcotics in India. The Customs \& Central Excise department was established in the year 1855 by the then British Governor General of India, to administer customs laws in India and collection of import duties/land revenue. It is one of the oldest government departments of India. Currently, the Customs and Excise department comes under the Department of Revenue, Ministry of Finance. [18]

Fishery Department

The district of Ratnagiri is known for its long coast line and suitable ports, together with its relative nearness to the Arabian Coast. Ratnagiri district is one of the most important maritime districts of the State with the coastal belt extending to about $167 \mathrm{kms}$. [19]

The Fisheries Office at Ratnagiri is one of the oldest district offices of the Fisheries Department. This office was started in 1936. Superintendent of Fisheries (Coast), Ratnagiri, is entrusted with the supervision of all fisheries activities and execution of fishery schemes in the district. 
The Marine Biological Research Station at Ratnagiri is concerned with conducting fishery-related research in the region [20].

Fishing industry in the district is mainly dependent upon the exploitation of marine resources. The ichthyologic fauna of Ratnagiri district is very rich comprising a good number of varieties viz. prawns, sharks, skates, rays, mackerals, sardines, tuna, pomfret, karel, and catfish. Prawn processing is carried out in a big scale which has a great demand abroad fishing season commences from September and lasts till the end of May. During the monsoon season, fishing activity practically comes to a halt except in the creeks. [21]

\section{Ashapura Minechem Pvt. Ltd.}

Ashapura Minechem is the flagship company of the Ashapura Group and well known as India's largest mine owner \& exporter of bentonite. It is among the top five global producers of bentonite with over 45 million tons of quality sodium and calcium bentonite reserves across the country. It has four decades of processing bentonite complemented by indigenous $\mathrm{R} \& \mathrm{D}$, the global technology and superior shipping \& port infrastructure. [22]

Usage by the general community members of the study villages

The beach of the study villages mostly serves as a place for relaxation. Often, it is used for small-time fishing. We have also reported the beach being used for open defecation. On occasions like Ganapati festival, the beach is the central location for idol immersion. In brief, major general use categories that emerged from our household survey are (i) relaxation, (ii) small time fishing, (iii) open defecation and, (iv) occasional miscellaneous activities like idol immersion. Among these categories, personal fishing is the most common use category. In all study villages, more than $20 \%$ of respondents mentioned it. Occasional use was the second common among all respondents. Per cent distribution of all respondents in various use categories in the study villages is presented in Table 4.

Stakeholders putting the beach to different usage - with focus on the quantity and quality of waste generated by them have been described in Figures 3, 4 and 5.

Table 4. Percentage of Because of Categories $(n=25)$.

\begin{tabular}{|c|c|c|c|}
\hline Parameter & Velas & Kelshi & Anjarla \\
\hline Coastline length $(\mathrm{km})$ & 2 & 5 & 2.5 \\
\hline \multicolumn{4}{|l|}{ Beach Usage (\%) } \\
\hline Relaxation & 17 & NA & 25 \\
\hline Defecation & NA & & 8 \\
\hline Occasional use & 58 & 67 & 46 \\
\hline
\end{tabular}

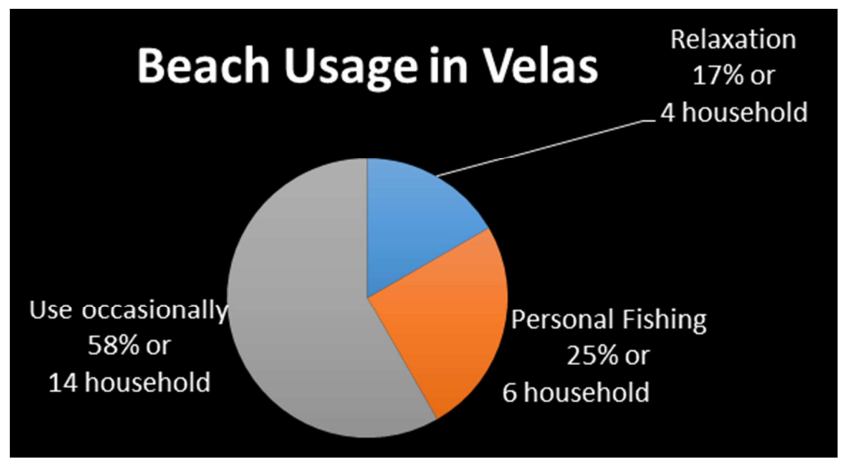

Figure 3. Velas Beach Usage Profile.

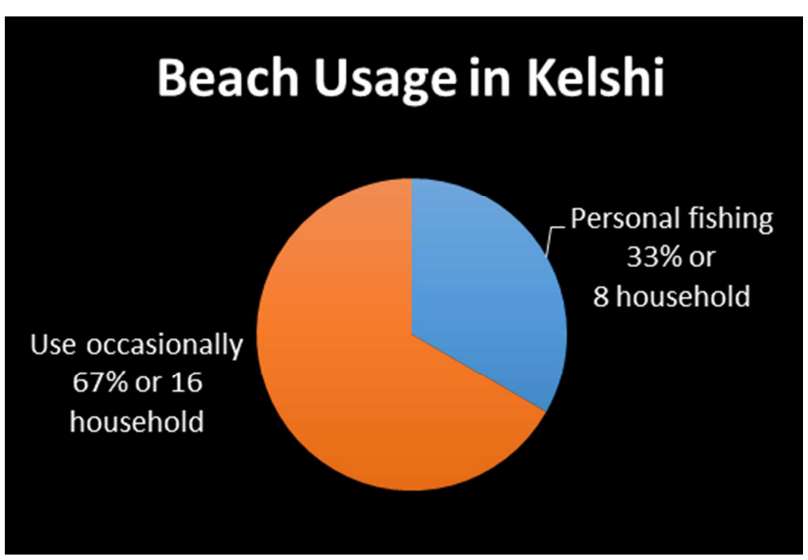

Figure 4. Kelshi Beach Usage.

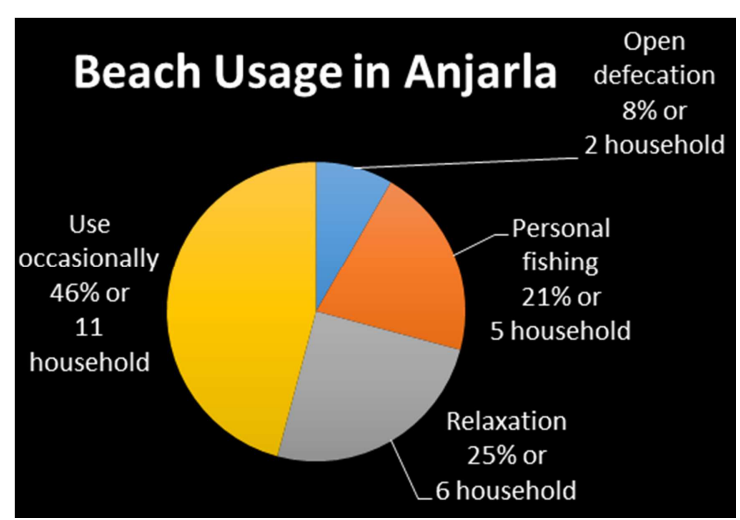

Figure 5. Anjarla Beach Usage.

\section{Tourism on the Beach}

Coastal villages in the Konkan region are richer in biodiversity than inland ecosystems as they have terrestrial as well as estuarine, inter-tidal, and marine biodiversity. In 2014, a Quick Biodiversity Valuation was conducted in the study villages to documented species diversity in the area. [23]

The beaches are an important aspect of coastal villages. They serve as a habitat for numerous species, especially nonvertebrates like molluscs and crustaceans. Mega fauna such as marine turtles use sandy beaches for mass nesting. Beaches are also very important from an economic perspective as they are an important site for tourism. Both biodiversity conservation and economic activities are important for beach management and need to be balanced to 
ensure that neither is negatively affected by management practices. Thus, destruction of biodiversity must be minimised, while ensuring that eco-friendly tourism practices are followed in coastal villages. The first step towards such a management regime is to identify stakeholders for beach management. [24]
Tourism is an everyday activity on Kelshi and Anjarla on the weekends throughout the year. In Velas, it is mostly confined to not more than 15 days during the turtle festival in February or March every year.

There are peak periods of tourism in a year. These peak tourism periods in each study village are listed in Table 5.

Table 5. Tourism Peaks the study villages.

\begin{tabular}{llll}
\hline Occasion & Time of the Year & Velas & Kelshi \\
\hline New Year's Eve/New Year & December-January & $\mathrm{N}$ & $\mathrm{Y}$ \\
Turtle Festival & February-March & $\mathrm{Y}$ & $\mathrm{Y}$ \\
Annual village festival & April & $\mathrm{Y}$ & $\mathrm{Y}$ \\
Ganapati Festival & August-September & $\mathrm{Y}$ & $\mathrm{Y}$ \\
Navratri & September-October & $\mathrm{Y}$ & $\mathrm{Y}$ \\
Deepawali & October-November & $\mathrm{Y}$ & $\mathrm{Y}$ \\
Long weekends & All year round & $\mathrm{Y}$ & $\mathrm{Y}$ \\
\hline
\end{tabular}

\section{Litter and Waste on the Beach}

Velas receives a significant amount of waste washed in by the tidal waves as compared to the other two study villages. Kelshi is cleaner than the rest two study villages. On all the three beaches strips of medicinal tablets, medicinal syrup bottles and syringes are common. General waste washed on the beach includes plastic waste, liquor bottles, empty milk packets, Thermocol used in packaging, footwear, and empty nylon gunny bags. Religious waste like flowers and coconuts the most common debris that is washed on the beach. Details of the beach litter profile are presented in Table 6 .

Table 6. Beach Litter Profile of the Study Villages.

\begin{tabular}{|c|c|c|c|c|}
\hline \multirow{2}{*}{ S. No. } & \multirow{2}{*}{ Type of waste } & \multicolumn{3}{|c|}{$\%$ of total waste measured during the investigation } \\
\hline & & Velas & Kelshi & Anjarla \\
\hline \multicolumn{5}{|c|}{ Degradable } \\
\hline 1 & Religious waste & 1 & 10 & 6 \\
\hline \multicolumn{5}{|c|}{ Non-degradable } \\
\hline 2 & Glass & 80 & 60 & 67 \\
\hline 3 & Plastic & 14 & 10 & 17 \\
\hline 4 & Rubber & 4 & 20 & 7 \\
\hline
\end{tabular}

Importantly, human faecal matter is prevalent. Its origin is in the open release of sewage in the open sea by the coastal villages. It is washed ashore by the high tide. In the study villages, most of the toilets have lined septic tanks. However, considerable a proportion of toilets, almost $30 \%$, release their waste in the open, either in the creek or as seepage in the soil (locally called Jirta). The proportion of toilet waste disposal is presented in Table 7.
Table 7. Toilet Waste Disposal in the Study Villages $(n=25)$.

\begin{tabular}{llll}
\hline & \multicolumn{3}{l}{$\%$ of toilet waste disposal system } \\
\cline { 2 - 4 } & Velas & Kelshi & Anjarla \\
\hline Lined Septic Tank & 72 & 64 & 68 \\
Drained directly into the creek & 8 & 28 & 8 \\
Seepage in the soil & 28 & 8 & 24 \\
\hline
\end{tabular}

Table 8. The volume of Litter on the Beach.

\begin{tabular}{|c|c|c|c|c|c|c|}
\hline \multirow{3}{*}{ Data Collection Period } & \multicolumn{6}{|c|}{ Weight of litter (kg) } \\
\hline & \multicolumn{2}{|l|}{ Velas } & \multicolumn{2}{|l|}{ Kelshi } & \multicolumn{2}{|l|}{ Anjarla } \\
\hline & Before tide & After tide & Before tide & After wave & Before tide & After wave \\
\hline November (Pre-tourism: Diwali) & $66^{1}$ & 0.5 & 1 & 0.5 & 1.5 & 0.75 \\
\hline November (During-tourism: Diwali) & 10 & 2 & 0.4 & 0.2 & 1.5 & 0.5 \\
\hline December (Pre-tourism: New Year) & $0^{2}$ & 0.5 & 0.25 & 0.5 & 0.2 & 0.1 \\
\hline December (During-tourism: New Year) & 5 & 0.5 & 0.3 & 0.5 & 2 & 0.6 \\
\hline
\end{tabular}

Table 9. Beach Litter Weight Before and After High Tide.

\begin{tabular}{llll}
\hline & Time-period of Data Collection & Before Tide (kg) & After Tide (kg) \\
\hline \multirow{4}{*}{ Velas } & November (Pre-tourism: Diwali) & $66.0^{*}$ & 0.5 \\
& November (During-tourism: Diwali) & 10.0 & 2.0 \\
& December (Pre-tourism: New Year) & $0.0^{* *}$ & 0.5 \\
& December (During-tourism: New Year) & 5.0 & 0.5 \\
\hline
\end{tabular}

1Abnormally high; data may be an outlier.

2Pre-turtle nesting voluntary cleaning had been carried out before sampling. 


\begin{tabular}{llll}
\hline & Time-period of Data Collection & Before Tide (kg) & After Tide (kg) \\
\hline \multirow{4}{*}{ Kelshi } & November (Pre-tourism: Diwali) & 1.0 & 0.5 \\
& November (During-tourism: Diwali) & 0.4 & 0.2 \\
& December (Pre-tourism: New Year) & 0.25 & 0.5 \\
& December (During-tourism: New Year) & 0.3 & 0.5 \\
\multirow{4}{*}{ Anjarle } & November (Pre-tourism: Diwali) & 1.5 & 0.75 \\
& November (During-tourism: Diwali) & 1.5 & 0.5 \\
& December (Pre-tourism: New Year) & 0.2 & 0.1 \\
& December (During-tourism: New Year) & 2.0 & 0.6 \\
\hline
\end{tabular}

*Abnormally high; data may be an outlier.

**Pre-turtle nesting voluntary cleaning had been carried out before

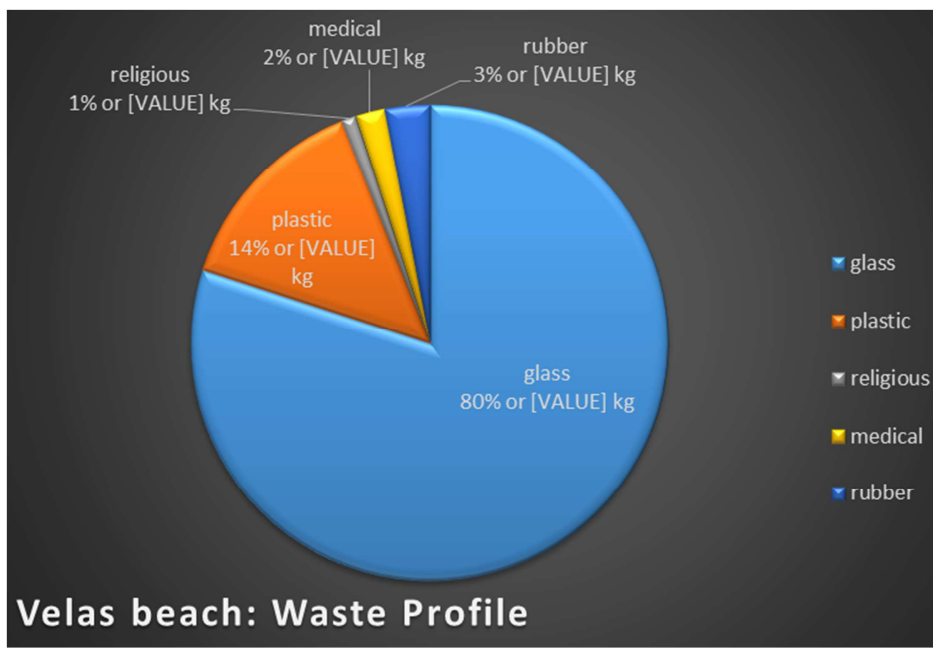

Figure 6. Velas Beach Litter Profile.

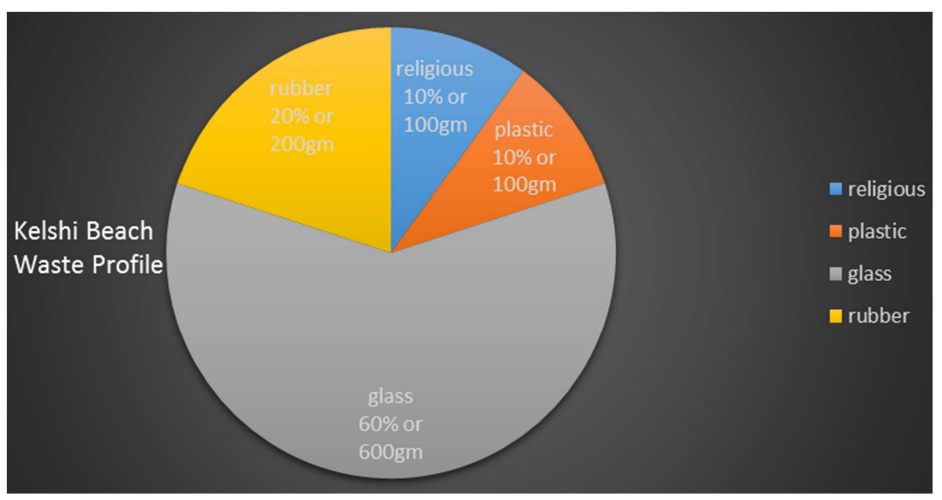

Figure 7. Kelshi Beach Litter Profile.

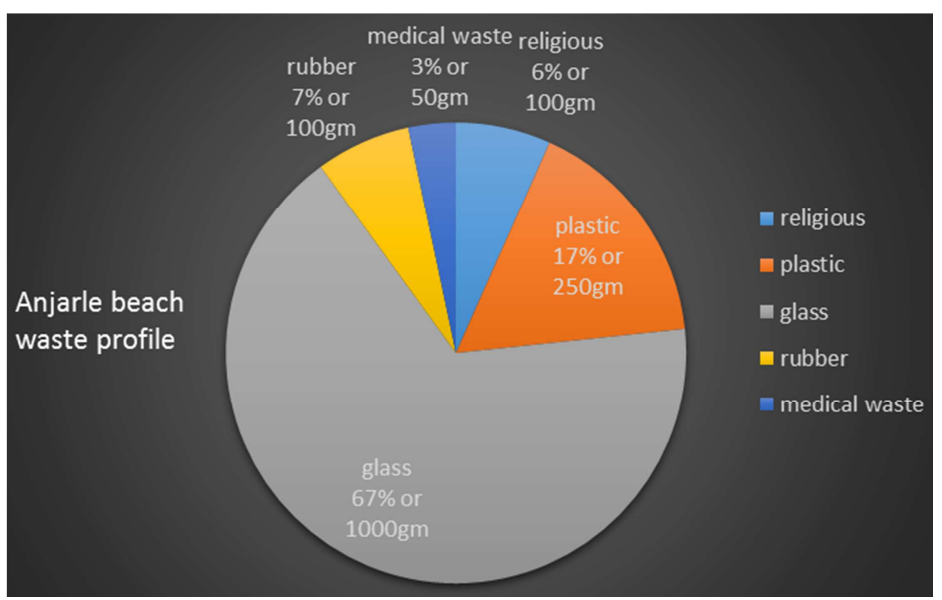

Figure 8. Anjarla Beach Litter Profile. 
On all the three beaches, human faecal matter was observed. These were found in two manners - in the form of a broken line along the high tide line, as though brought in by the high tide (recognisable as human faecal matter) and also present on the beach due to those practising open defecation. Hence, people defecating inside toilets were also probably contributing to the beach faecal matter, perhaps because their bathrooms were leading right into the creek (especially in the case of creek-side dwellers - Kinara mohalla in Kelshi, Danda community in Velas and Bandarwada in Anjarla) or in an informal drain network that drained into the creek.

The Gram Panchayat is responsible for septic tank cleanup of public toilets and roadside drains.

In Velas, there were no public toilets. In Anjarla, all public restrooms were jirta, as per Gram Panchayat discussion. In Kelshi, clean-up schedule of public toilets could not be determined.

In Velas, the Gram Panchayat mentioned cleaning roadside ditches once a year, before the monsoons. In Kelshi, this was thrice annually while in Anjarla the schedule was reportedly irregular. None of the Gram Panchayats shared a sludge management plan for the sludge they removed from the roadside ditches or sewage sludge management plan for the public toilets' septic tanks.

In jirta toilets, the sewage sludge is difficult to take out as the so-called septic tanks are unlined and the mud mixes with soil. In toilets directly draining into the creek, the faecal matter directly enters the sea. Most of the houses with lined septic tank were new, and hence, the tanks were not full yet they had not undergone their first cleaning, however.

The high tide was found to bring an average of $0.68 \mathrm{~kg}$ of waste to the three beaches. The average litter washed down to Velas beach by the high tide was higher than that in the two other beaches $(0.88 \mathrm{~kg}$, as compared to $0.42 \mathrm{~kg}$ in Kelshi and $0.48 \mathrm{~kg}$ in Anjarla). The bridge construction activity near Velas may be responsible for the relatively more substantial quantity of waste being brought in by the high tide.

Another observation was that, the impact of tourist activity on the beach. During Diwali, in Velas and Kelshi, the duringtourism beach litter weight before high tide was lesser than pre-tourism readings while both readings were equal for Anjarla beach. However, during New Year eve, the beach litter weights in Velas and Anjarla beaches were considerably higher ( 5 times more and ten times more than pre-tourism readings), though pre-tourism and during-tourism readings were nearly similar for Kelshi. This indicates that during New Year, the beaches at the three villages are at higher tourist pressure, in terms of solid waste.

With the tireless social activities of Sahyadri Nisarg Mitra, Velas villagers are much more ecologically literate and conscious than their counterparts in the other villages studied. Villagers themselves undertake beach clean-up drives, voluntarily. Also, M/s Infrastructure Logistics Pvt. Ltd., Mandangad were responsible for Vela's beach clean-up activity. The schedule of their beach management activity could not be determined.
As a part of their Corporate Social Responsibility (CSR) initiative, M/s Ashapura Minechem Pvt. Ltd. has undertaken the clean-up of Kelshi beach. However, their schedule of the clean-up could not be determined. For the beach to remain clean, precise coordination between peak tourism periods and beach clean-up drive must be ensured.

Beach litter management practices were reported to be conducted by school children, but only before the turtle festival.

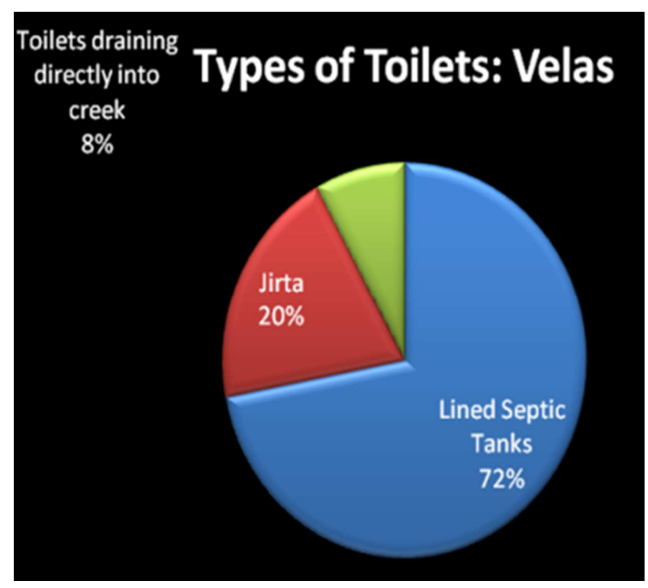

Figure 9. Types of Toilets in Velas.

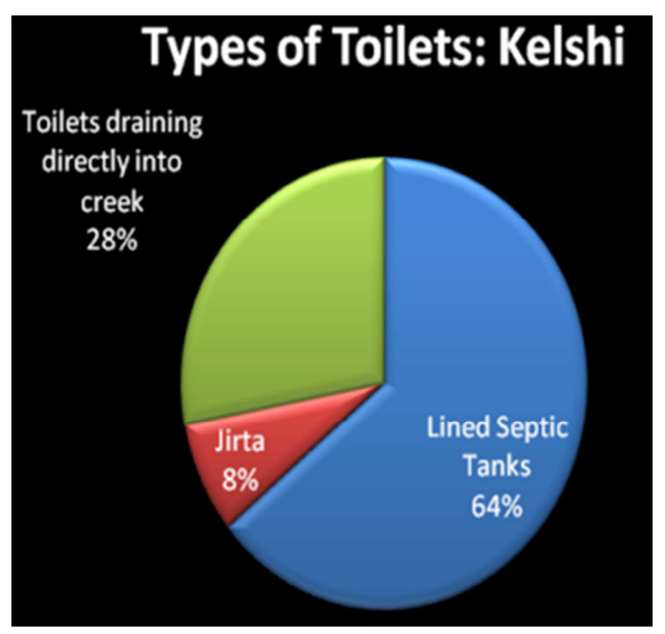

Figure 10. Types of Toilets in Velas, Kelshi.

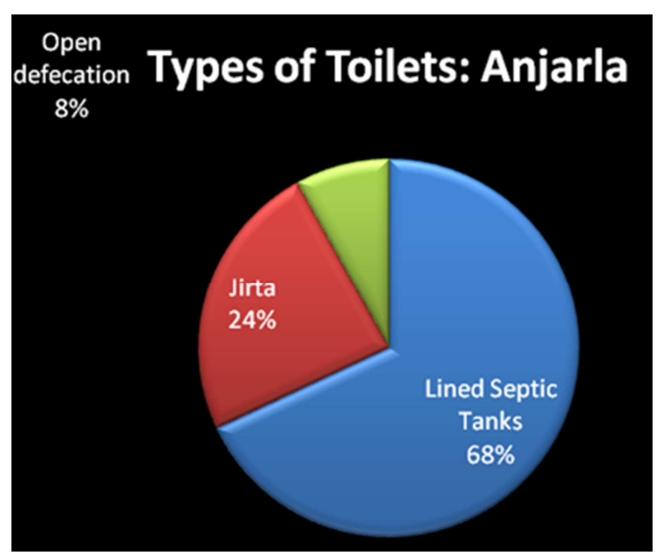

Figure 11. Types of Toilets in Anjarla. 


\section{Discussion}

Some significant challenges and weaknesses in the beach management in the study villages

The CSR activity of M/s Ashapura Minechem Pvt. Ltd. and $\mathrm{M} / \mathrm{s}$ Infrastructure Logistics Pvt. Ltd. appears unplanned and irregular. This can be inferred from the fact that local villagers do not have any idea of the time table of the beach clean-up activity. This must be better managed and planned to ensure that beach clean-up activities coincide with high incidences of beach litter, e.g., Ganapati festival, before turtle nesting.

Open defecation is practised in Anjarla (admitted by $8 \%$ of surveyed individuals) and by labourers of M/s Ashapura Minechem Pvt. Ltd. in Kelshi.

Recreation activity like riding a motorbike on the beach is observed in Kelshi. As of now, it is almost negligible. However, this may not be so in the future. It may escalate into free tourist recreation activities like riding sand bikes and parasailing being done in Harne, Murad, Ladghar and other adjacent beaches. For the beach ecosystem, such events are harmful. Gram Panchayat, Biodiversity Management Committee and other concerned authorities should keep a strict check on such activities.

Hamlets adjacent to the creek (Danda area in Velas, Kinara mohalla in Kelshi and Bhandarwada in Anjarla) in the study villages invariably dispose of their solid waste directly into the river - this waste may make its way to the nearby beaches during high tide. Some adequate waste segregation and management system should be set up so that environmentally harmful disposal practices are appropriately addressed.

\section{Conclusion}

The local villagers are not aware about the rules and timing of cleaning of beach activities. This can be better managed and planned to ensure that villagers regular activities and their working timing which should not coincide with high incidences of beach management. Open defecation is avoided only by giving facilities and making them feel that why it is so important and how it can contribute their one initiative to make a big change in the beach tourism. Many migrant labourers working in that area reported the reason of open defecation is due to lack of proper facilities to support the large inflow of migrants in Kelshi. Recreation activities can be increased by supporting small changes in these places which will certainly increase the economic condition and will create more jobs in those areas e.g. riding motorbikes on the beach provide a kind of earning model those who are not getting money from any of the sources. As of now this is almost negligible but may increase in the future. It may escalate into uncontrolled tourist recreation activities like riding sand bikes and para-sailing in Harne, Murud, Ladghar, and other adjacent beaches.

But overuse or overpromotion of such activities are harmful for the beach ecosystem. Gram Panchayat, BMCs and other concerned authorities must remain vigilant to control such activities.

\section{References}

[1] http://www.eol.org/pages/1056177/overview.

[2] Ocana, M. A. S. (2010). Arribada nesting of olive ridley sea turtles (Lepidochelys olivacea) at La Escobilla, Mexico.

[3] http://www.wwfindia.org/about_wwf/priority_species/lesser_ known_species/olive_ridley_turtle/.

[4] Shanker, K., Pandav, B., \& Choudhury, B. C. (2004). An assessment of the olive ridley turtle (Lepidochelys olivacea) nesting population in Orissa, India. Biological Conservation, $115(1), 149-160$

[5] Martin, J. M. (2013). Marine debris removal: one year of effort by the Georgia Sea Turtle-Center-Marine Debris Initiative. Marine pollution bulletin, 74 (1), 165-169.

[6] Campbell, L. M. (1999). Ecotourism in rural developing communities. Annals of tourism research, 26 (3), 534-553.

[7] Israel, Glenn D. (1992). Sampling The Evidence Of Extension Program Impact. Program Evaluation and Organizational Development, IFAS, University of Florida. PEOD-5. October.

[8] Schulz, M., Neumann, D., Fleet, D. M., \& Matthies, M. (2013). A multi-criteria evaluation system for marine litter pollution based on statistical analyses of OSPAR beach litter monitoring time series. Marine environmental research, 92, 61-70.

[9] http://www.ospar.org/organisation/contracting-parties.

[10] http://www.ospar.org/documents?v=7058.

[11] http://www.maharashtrapoliticalparties.in/grampanchayat.html.

[12] http://frienvis.nic.in/database/joint_forest_management_1949. aspx.

[13] http://mangrovecell.org/.

[14] http://legislative.gov.in/constitution-seventy-thirdamendment-act-1992.

[15] http://www.indiancoastguard.nic.in/.

[16] FICCI (2017). Smart border management: Indian coastal and maritime security. http://ficci.in/spdocument/20955/SmartBorder-Management-study.pdf.

[17] (Indian Coast guard, Ministry of Défense Retrieved from https://www.indiancoastguard.gov.in/content/287_3_AreaofR esponsibility.aspx.

[18] http://www.punecustoms.nic.in/ratnagiri.htm.

[19] Marine Fisheries Information Service (1998), Central Marine Fisheries Research Centre, Cochin, India.

[20] http://ratnagiri.nic.in/gazetter/gom/dev_dept_fisheries.html.

[21] Adarsh Machimar Society, Mirkarwada March (2012).

[22] http://www.ashapura.com/ashapuraminechem.htm.

[23] http://mpcb.gov.in/notices/Summary/UTTAMBAR BAUXIT E_DEPOSIT.pdf. 
[24] Patwardhan, A. (2014). Report on Rapid Biodiversity Assessment of Coastal Habitat for Implementation of a Startup Phase in the Velas-Anjarle Coastal Stretch, Maharashtra, for Conservation and Sustainable Management of Existing and Potential Areas (CMPA). Sahyadri Nisarga Mitra, Chiplun, Maharashtra. 